\title{
Mathematical Model for Reducing the Concentration of a Chemical Substance Applicable in the Procedures of Plasmatic Treatment
}

\author{
CIPRIAN MIHAI GINDAC ${ }^{1,2}$, OVIDIU HOREA BEDREAG ${ }^{1,2}$, LAURA ALEXANDRA NUSSBAUM ${ }^{3 *}$, IULIA BIANCA MICU SERBU ${ }^{3}$, \\ ROXANA FOLESCU4*, MIRELA GRIGORAS ${ }^{4}$, LAVINIA MARIA HOGEA3 ${ }^{3}$ MIHAELA ADRIANA SIMU3*, VIOREL LUPU, \\ MIHAELA BOANCA ${ }^{6}$, DOREL SANDESC ${ }^{1,2}$ \\ ${ }^{1}$ Emergency County Hospital Pius Brinzeu, Department of Anaesthesia and Intensive Care, 156 L. Rebreanu Blvd, Timisoara, \\ 300723, Romania \\ ${ }^{2}$ Victor Babes University of Medicine and Pharmacy, Department of Anaesthesia and Intensive Care, 2 Eftimie Murgu Sq, \\ Timisoara, 300041, Romania \\ ${ }^{3}$ Victor Babes University of Medicine and Pharmacy, Department of Neurosciences, 2 Eftimie Murgu Sq, Timisoara, 300041, \\ Romania \\ 4Victor Babes University of Medicine and Pharmacy, Department of Anatomy and Embryology, 2 Eftimie Murgu Sq., 300041, \\ Timisoara, Romania \\ ${ }^{5}$ Iuliu Hatieganu University of Medicine and Pharmacy, Department of Psychiatry and Child Psychiatry, Ospataritei Sq., 400000, \\ Cluj-Napoca, Romania \\ ${ }^{6}$ Grigore T. Popa University of Medicine and Pharmacy, Faculty of Medicine, 16 Universitatii Str., 700115 Iasi, Romania
}

\begin{abstract}
The objective was to study the correlation between the mathematical form of a chemical that we want to lower its initial concentration by the regressive method and the purging of the body's toxic presentchemicals that need to be eliminated. We developed a chemical model, by which, to a given volume, with a certain ( $X$ - concentration \%) dissolved substance in a container, the initial solvent, withoutsolvit, is added (concentration $0 \%$ ) with an equal rhythm to the one that is lost from the used container. The solution that will be lost will contain less and less concentrations of solvit, compared to the initial value X\%. At the same time, the concentration of our chemical model will decrease. We applied a regressive mathematical formula to this model in order to calculate the concentration in the container in each moment. At the same time, we conducted treatment sessions in patients in which certain substances need to be eliminated, a procedure that complies with the described chemical model. We have demonstrated that at the same volume of $0 \%$ solvit wash, the substance purging with X\% concentration is more effective, if the procedure starts with an initial loss of concentrated substance, with ulterior volume replacement. Laboratory data confirms the mathematical model in patients who started the procedure with plasma loss. The developed chemical model demonstrates that the initial loss of substance, hastens the decrease of the initial concentration, especially as the loss is higher at the beginning of the procedure if we use the same replacement volume without the substance in the initial solution. This model can be applied in plasma treatment methods in order to study the patient's safety and the amount of plasma the patient can lose at the beginning.
\end{abstract}

Keywords: mathematical model, TPE (therapeutical plasma exchange), volume replacement, plasma purge

In most cases, the substitution solutions used in plasma purification techniques, by plasmapheresis, are represented by freshly frozen plasma (FFP) and albumin [1-3]. These solutions are used in TPE (therapeutical plasma exchange), representing the treatment of over 100 pathologies.

Over the past 20 years, this type of treatment has been increasingly used, targeting new indications the field of neurology, nephrology, haematology, and especially in pathologies with immunological substrate $[4,5]$.

Their lack in sufficient quantities and their high cost requires efficient use. Note that for an adult of $70 \mathrm{~kg}$ in a single TPE session, about 15 FFP bags are required, the recommendation advocating 4-7 sessions. The use of a lower number of bags with the same effectiveness is a desideratum that we are trying to achieve [5].

In these procedures it is desirable to remove from organism chemicals or products that are in elevated concentrations: autoantibodies that are fixed by the links of $\mathrm{H}_{2} \mathrm{~N}$-antigens, bilirubin - $\mathrm{C}_{33} \mathrm{H}_{36} \mathrm{NO}$, triglycerides $\mathrm{C}_{55} \mathrm{H}_{98}^{2} \mathrm{O}_{6^{\prime}}$ heavy metals ( $\mathrm{Hg}$, $\mathrm{PB}^{33}$ etc. $)^{4}$, alpha amanitin $\mathrm{C}_{39}^{5} \mathrm{H}_{54}^{98} \mathrm{~N}_{10}^{6} \mathrm{O}_{14} \mathrm{~S}$, creatinine - $\mathrm{C}_{4} \mathrm{H}_{2} \mathrm{~N}_{3} \mathrm{O}_{5}$, and ureea - $\mathrm{CH}_{4} \mathrm{~N}_{2} \mathrm{O}$ $[6,7]$.

\section{Experimental part}

In our study, we used a heterogeneous lot of 18 adult patients to whom we applied a procedure of plasma drawdown. There were patients with autoimmune neurological pathologies, myasthenia gravis and polyradiculoneuritis.

The chemical model of elevated plasma concentrations of these substances could be extremely easily lowered in vitro. If we consider the plasma volume a $3 \mathrm{~L}$ container with a concentration of substance that we want to lower, we would throw the entire container and put $3 \mathrm{~L}$ of clean plasma ( $0 \%$ concentration of the substance we want to eliminate) (fig.1).

The plasma purge procedure involves the elimination of dirty plasma drop by drop (with high concentration of toxic substance) and replacing it at the same rhythm with pure plasma.

Our in vitro model implies calculating at every moment of the procedure the concentration in the container according to their placement volume, used until that time.

For this calculation we use a mathematical function exported to Excel, where the drop's place is taken by an arbitrary volume of $100 \mathrm{~mL}$, the container will have 3000

* email: nussbaumlaura@yahoo.com,roxanafolescu08@gmail.com; mihaelasimu6713@gmail.com 


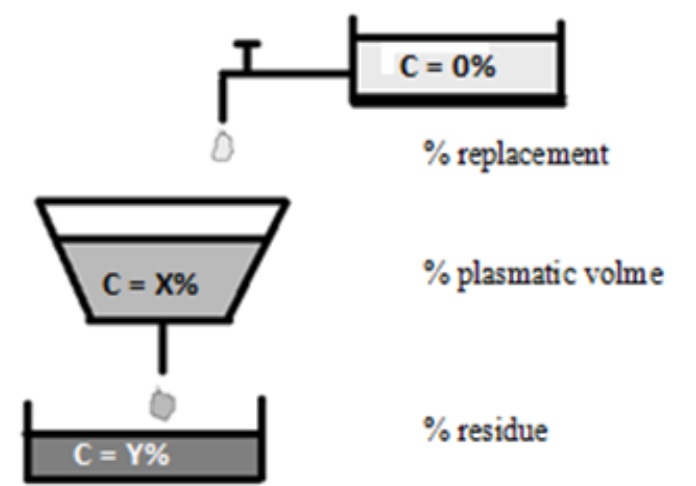

Fig. 1. Scheme of a plasmatic treatment procedure

$\mathrm{mL}$ and the replacement volume will also count $3000 \mathrm{~mL}$. The literature considers the 1:1 ratio, as minimally required for an effective session. Thus, we will initially have 3000 $\mathrm{mL}$ replacement volume, $3000 \mathrm{~mL}$ plasma volume and 0 $\mathrm{mL}$ residue. In the middle of the session, there placement will be equal to the residue $(1500 \mathrm{~mL})$, and the plasma volume will be $3000 \mathrm{~mL}$ constant. At the end of the session the replacement will be $0 \mathrm{~mL}, 3000 \mathrm{~mL}$ residue and 3000 $\mathrm{mL}$ constant plasma volume.

\section{Results and discussions}

We consider a chemical substance plasma concentration of $10 \%$ and we eliminate $100 \mathrm{~mL}$ of plasma volume with a concentration of $10 \%$ and add $100 \mathrm{~mL}$ of replacement with $0 \%$ concentration.

Thus, in the central container we have $10 \%$ of $3000 \mathrm{~mL}$, the equivalent of $300 \mathrm{~g}$. Eliminating $100 \mathrm{~mL}$ of $10 \%$, the equivalent of $10 \mathrm{~g}$ and adding $100 \mathrm{~mL} 0 \%$, in the container we will have $290 \mathrm{~g}$ that represent a concentration of $9.66 \%$. Continuing this pattern until the end of the procedure, we will have 30 steps that we importfrom an Excel table where we apply the following mathematical regression function [8-14].

In A column we have the remaining in the container solvit in grams, and in C column, its concentration in solution at a certain time (table 1 ).

According to data presented in table 1, we will have the following plasma concentrations:

C1: $300 \mathrm{mg} / 3000 \mathrm{~mL}=10 \%$

C2: $(300 \mathrm{mg}-300 \mathrm{mg} \times 100 \mathrm{~mL} / 3000 \mathrm{~mL}) / 3000 \mathrm{~mL}=$ $290 \mathrm{mg} / 3000 \mathrm{~mL}=9.67 \%$

C3: $(290 \mathrm{mg}-290 \mathrm{mg} \times 100 \mathrm{~mL} / 3000 \mathrm{~mL}) / 3000 \mathrm{~mL}=$ $280.33 \mathrm{mg} / 3000 \mathrm{~mL}=9.34 \%$

\section{C9: $7.37 \%$}

C20: $5.25 \%$

C30: $3.74 \%$

Using this mathematical calculation at the end of the given process, we will have a $3.74 \%$ concentration of the chemical in the container that from a medical point of view represents a cleaning of $62.6 \%$.

This calculation corresponds to the literature data [1517], alleging that the use of a replacement volume equal to the plasma volume achieves a $63 \%$ purging (table 2 ).

Next we will try to calculate what happens if we remove an arbitrary volume of $1000 \mathrm{~mL}$ from the container, replace it with $1000 \mathrm{~mL}$ of $0 \%$ solution, and further proceed with the elimination of $100 \mathrm{~mL}$ while replacing with other clean $100 \mathrm{~mL}$. We will remove $100 \mathrm{mg}$ of substance and start the process with another 20 steps ( 10 we consider: 1000 $\mathrm{mL}=100 \times 10$ steps). The new calculated purged percentage will be $66.1 \%$, $5 \%$ higher than $63 \%$, the percentage calculated in the previous paragraph.

This demonstrates that any loss, at any time, increases the effectiveness of the purge even if the replacement is

\begin{tabular}{|r|r|r|}
\hline \multicolumn{3}{|c}{$=$} \\
\hline \multicolumn{3}{|c}{ SUM(A1-A1*100/3000) } \\
\hline 1 & \multicolumn{1}{|c}{ A } & B \\
\hline 2 & 290 & 0.1 \\
\hline 3 & 280.333 & 0.0967 \\
\hline 4 & 270.989 & 0.0934 \\
\hline 5 & 261.956 & 0.0803 \\
\hline 6 & 253.224 & 0.0844 \\
\hline 7 & 244.783 & 0.0816 \\
\hline 8 & 236.624 & 0.0789 \\
\hline 9 & 228.736 & 0.0762 \\
\hline 10 & 221.112 & 0.0737 \\
\hline 20 & 157.536 & 0.0525 \\
\hline 21 & 152.285 & 0.0508 \\
\hline 22 & 147.208 & 0.0491 \\
\hline 23 & 142.302 & 0.0474 \\
\hline 24 & 137.558 & 0.0459 \\
\hline 25 & 132.973 & 0.0443 \\
\hline 26 & 128.54 & 0.0428 \\
\hline 27 & 124.256 & 0.0414 \\
\hline 28 & 120.114 & 0.04 \\
\hline 29 & 116.11 & 0.0387 \\
\hline 30 & 112.24 & 0.0374 \\
\hline 31 & 108.5 & 0.036 \\
\hline & & \\
\hline
\end{tabular}

Table 1

THE REMAINING IN THE CONTAINER SOLVIT IN GRAMS - A COLUMN

\begin{tabular}{|c|c|c|}
\hline $\begin{array}{c}\text { X times plasma } \\
\text { changed }\end{array}$ & $\mathrm{Cf} / \mathrm{Ci}$ & $\begin{array}{c}\text { Clearance } \\
(1-\mathrm{Cf} / \mathrm{Ci})\end{array}$ \\
\hline 0.8 & 0.508 & 0.492 \\
\hline $\mathbf{l . 0}$ & $\mathbf{0 . 3 6 8}$ & $\mathbf{0 . 6 3 2}$ \\
\hline 1.2 & 0.301 & 0.699 \\
\hline 1.3 & 0.272 & 0.727 \\
\hline 1.4 & 0.247 & 0.753 \\
\hline 1.6 & 0.202 & 0.798 \\
\hline 1.7 & 0.182 & 0.818 \\
\hline 1.8 & 0.165 & 0.835 \\
\hline 2.0 & 0.135 & 0.865 \\
\hline
\end{tabular}

Table 2

ELIMINATION ACCORDING TO PLASMACHANGED, THE RATIO BETWEEN THE FINAL (Cf) AND THE INITIAL (Ci) CONCENTRATION

used immediately after, which corresponds to literature data [18-23] (table 3).

The nextaspect we aim to demonstrate is whathappens to the whole process in terms of purging if this initial loss (from $100 \mathrm{~mL}$ to $1000 \mathrm{~mL}$ ) is not replaced. We will apply the same chemical model in which, of the $3000 \mathrm{~mL}$, were move a variable quantity that we no longer replace, following the steps model, with a loss of $100 \mathrm{~mL}$ from the container and replacement of $100 \mathrm{~mL}$ with $0 \%$ concentration, and in the end, we add the lost quantity (table 4). In this case we will have even greater effectiveness of the process. At $300 \mathrm{~mL}$ loss, we will have a purge of $69 \%$ ( $100 \%$ - $97.45 / 3 \mathrm{~L})$, at a $500 \mathrm{~mL}$ loss we will have a purge of $70.2 \%(100 \%-90.09 / 3 \mathrm{~L})$ and at a stop of 


\begin{tabular}{|c|r|r|}
\hline \multicolumn{3}{|c|}{$=$ SUM $\left(\mathrm{C} 1-\mathrm{C} 1{ }^{*} 100 / 3000\right)$} \\
\hline \multicolumn{1}{|c|}{$\mathrm{C}$} & $\mathrm{D}$ \\
\hline 1 & 200 & 0.066667 \\
\cline { 2 - 3 } & 193.333 & 0.064444 \\
\hline 3 & 186.889 & 0.062296 \\
\hline 4 & 180.659 & 0.06022 \\
\hline 5 & 174.637 & 0.058212 \\
\hline 6 & 168.816 & 0.056272 \\
\hline 7 & 163.189 & 0.054396 \\
\hline 8 & 157.749 & 0.052583 \\
\hline 9 & 152.491 & 0.05083 \\
\hline 10 & 147.408 & 0.049136 \\
\hline 20 & 105.024 & 0.035008 \\
\hline 21 & 101.523 & 0.033841 \\
\hline 22 & & \\
\hline
\end{tabular}

$1000 \mathrm{~mL}$, a purge of $76 \%(100 \%-71.68 / 3 \mathrm{~L})$, which corresponds to literature data [24-26].

This calculation demonstrates that any loss from the container at the beginning of the procedure, increases the effectiveness of the purge and that this is even greater as higher is the loss, in accord to literature [27, 28].

If we consider the container in the experiment the plasma volume of approximately $3000 \mathrm{~mL}$ for an adult of $70 \mathrm{~kg}$, as shown in the literature [29-31], in the process of plasma purification any loss of plasma at the beginning of the procedure increases its effectiveness.

This process is even more important when the plasma loss is higher at the beginning of the procedure, than if this loss is replaced, until the end of the procedure, by fewer volumes.

If we consider the high costs of FFP or albumin, and the reduced FFP quantities availability in the territorial transfusion centers, effective TPE sessions can be done with the same results if we apply the presented plasma loss chemical model [32, 33].

In order to verify the practical applicability of the theory that we have demonstrated, we have used this procedure in patients. Because the plasma volume of a patient does not behave exactly as a container model, we have closely monitorized the hemodynamic impact that the plasma clearance can have. When the patient's' clinical condition allowed the plasma loss (hemodynamically stable patients, water retention patients), we started the procedure of plasma loss (between 700 and $1000 \mathrm{~mL}$ ). Being hospitalized to Intensive Care, the hemodynamic impact has been closely monitorized. When tension decrease becomes important, plasma loss is stopped immediately, and $10 \%$ to $500 \mathrm{~mL}$ albumin replenishing is progressively performed, while the process continues with a standard TPE procedure where the draw down is equal step by step with the replacement $[29,32]$.

We monitored the hemodynamic effect in plasma loss and followed the clinically effect of the procedure. In 10 sessions in patients with myasthenia gravis we measured acetylcholine receptors antibodies at the beginning of a session and at the end of it (table 5).

The decrease in antibody titer was similar to that predicted theoretically in our chemical experiment and much higher than in the medical literature current data on the amount of replacement used. Clinical efficacy was also present in all cases at 24-48 $\mathrm{h}$ after the treatment was performed [31, 33].

If we try to calculate the quantities of replacements we save in order to have the same purification effectiveness, we will get the following results.

For a replacement of:

$200 \mathrm{~mL}$ we will save $350 \mathrm{~mL}$ (1.5 FFP bags)

$500 \mathrm{~mL}$ we will save $750 \mathrm{~mL}$ (3 FFP bags)

$700 \mathrm{~mL}$ we will save $900 \mathrm{~mL}$ (4.5 FFP bags)

$1000 \mathrm{~mL}$ we will save $1400 \mathrm{~mL}$ (7 FFP bags) - 7x150 EUR $=$ approx. 1000 EUR.

\begin{tabular}{|c|c|c|c|c|}
\hline \multicolumn{4}{|c|}{$=$ SUM $(I 1-I 1 * 100 / 2000)$} & \multirow{21}{*}{$\begin{array}{c}\text { Table } 4 \\
\text { CONCENTRATIONS } \\
\text { AFTER LOSS } \\
\text { WITHOUT REPLACE }\end{array}$} \\
\hline 4 & G & H & I & \\
\hline 1 & 270 & 250 & 200 & \\
\hline 2 & 260 & 240 & 190 & \\
\hline 3 & 250.3704 & 230.4 & 180.5 & \\
\hline 4 & 241.0974 & 221.184 & 171.475 & \\
\hline 5 & 232.1679 & 212.3366 & 162.9013 & \\
\hline 6 & 223.5691 & 203.8432 & 154.7562 & \\
\hline 7 & 215.2887 & 195.6894 & 147.0184 & \\
\hline 8 & 207.3151 & 187.8619 & 139.6675 & \\
\hline 9 & 199.6367 & 180.3474 & 132.6841 & \\
\hline 10 & 192.2428 & 173.1335 & 126.0499 & \\
\hline 20 & 131.8092 & 115.1048 & 75.47072 & \\
\hline 21 & 126.9274 & 110.5006 & 71.69718 & \\
\hline 22 & 122.2264 & 106.0806 & & \\
\hline 23 & 117.6995 & 101.8374 & & \\
\hline 24 & 113.3403 & 97.76387 & & \\
\hline 25 & 109.1425 & 93.85331 & & \\
\hline 26 & 105.1002 & 90.09918 & & \\
\hline 27 & 101.2076 & & & \\
\hline 28 & 97.45913 & & & \\
\hline
\end{tabular}

\begin{tabular}{|c|c|c|c|c|c|c|}
\hline \multirow[t]{2}{*}{ No } & \multirow[t]{2}{*}{ Weight } & \multirow[t]{2}{*}{ Hematocrit } & \multirow{2}{*}{$\begin{array}{l}\text { Patient estimated } \\
\text { plasma volume (mL) }\end{array}$} & \multicolumn{2}{|c|}{ Ac nmol/liter } & \multirow{2}{*}{$\begin{array}{l}\text { Clearance } \\
\text { Protocol }\end{array}$} \\
\hline & & & & Before & After & \\
\hline 1 & 76 & 36 & 3040 & 9.128 & 2.241 & $75 \%$ \\
\hline 2 & 75 & 35 & 3000 & 5.547 & 1.181 & $80 \%$ \\
\hline 3 & 92 & 32 & 3680 & 0.978 & 0.147 & $85 \%$ \\
\hline 4 & 74 & 39 & 2860 & 4.814 & 1.145 & $77 \%$ \\
\hline 5 & 72 & 37 & 2880 & 2.509 & 0.552 & $78 \%$ \\
\hline 6 & 72 & 35 & 2920 & 2.091 & 0.504 & $76 \%$ \\
\hline 7 & 85 & 34 & 3400 & 10.415 & 3.233 & $70 \%$ \\
\hline 8 & 85 & 31 & 3440 & 3.369 & 1.28 & $66 \%$ \\
\hline 9 & 55 & 41 & 2470 & 0.394 & 0.100 & $75 \%$ \\
\hline 10 & 55 & 39 & 2510 & 0.367 & 0.070 & $81 \%$ \\
\hline
\end{tabular}

Table 5

THE VALUE OF ANTIBODIES (FOR ACETYLCHOLINE RECEPTORS) BEFORE AND AFTER THE SESSION OF TPE THROUGH THE PROTOCOL WITH THE INITIAL LOSS OF $100 \mathrm{~mL}$ OF PLASMA 


\section{Conclusions}

If we have a container with a chemical diluted volume, in a given concentration, above which we add the same solvent without chemical substance, with a flow equal to that by which the substance is leaking from the container, the chemical substance purging process is even greater, as at the beginning of the process we have a bigger loss, and the replacement is later. If we extrapolate the chemical dilution process into a therapeutic plasma exchange session (TPE), the effectiveness of a TPE session is seven greater, as the plasma loss is more important at the beginning of the session, and the longer there placement is added, so that the patient's plasma volume does not undergo any significant changes. The plasma loss process should be performed under full hemodynamic monitoring in the Intensive Care Unit.

\section{References}

1.NOIRI, E., HANAFUSA, N., Concise Manual of Apheresis Therapy, Springer, Japan, 2014.

2.SCHWARTZ, J., PADMANABHAN, A., AQUI, N., BALOGUN, R.A., CONNELLY-SMITH, L., DELANEY, M., DUNBAR, N.M., WITT, V., WU, Y., SHAZ, B.H., J. Clin. Apher., 31, No. 3., 2016, p. 149.

3.KAPLAN, A.A., Ther. Apher., 3, No. 1, 1999, p.25.

4.WILLIAMS, M.E., BALOGUN, R.A., Clin. J. Am. Soc. Nephrol., 9, No. 1, 2014, p. 181.

5.GUYATT, G.H., OXMAN, A.D., VIST, G.E., KUNZ, R., FALCK-YTTER, Y., ALONSO-COELLO, P., SCHUNEMANN, H.J., BMJ Clin. Res., 336, No. 2, 2008, p. 924.

6.ATKINS, D., BRISS, P.A., ECCLES, M., FLOTTORP, S., GUYATT, G.H., HARBOUR, R.T., HILL, S., JAESCHKE, R., LIBERATI, A., MAGRINI, N., MASON, J., O'CONNELL, D., OXMAN, A.D., PHILLIPS, B., SCHUNEMANN, H., EDEJER, T.T., VIST, G.E., WILLIAMS, J.W., JR., BMC Health Serv. Res., 5, No. 3, 2005, p. 25.

7.DANILA, E.P., PRICOP, C., MITU, F., LEUSTEAN, L., MITU, O., VOICU, P.M., BORDEIANU, G., DIMITRIU, D.C., Rev. Chim. (Bucharest), 67, no. 3, 2016, p. 496.

8.MCLEOD BC, J. Clin. Apher., 17, No. 2, 2002, p. 124.

9.ANDOR, B., PATRASCU, J.M., FLORESCU, S., COJ OCARU, D., SANDESC, M., BORCAN, F., BORUGA, O., BOLINTINEANU, S., Mat. Plast., 53, no. 1, 2016, p. 120.

10.ALBAI, A., SIMA, A., PAPAVA, I., ROMAN, D., ANDOR, B., GAFENCU, M., Patient Preference and Adherence, 11, 2017, p. 1235.

11.HOGEA, L.M., HOGEA, B.G., NUSSBAUM, L.A., et al, Rom. J . Morphol. Embryol., 58, No. 1, 2017, p. 175.

12.CHIRIAC, V.D., HOGEA, L.M., BREDICEAN, A.C., et al, Rom. J. Morphol. Embryol., 58, No. 3, 2017, p. 1023.

13.HOGEA, B. G., PATRASCU, J.M. J R., SANDESC, M.A., Rom. J. Morphol. Embryol., 59, No. 3, 2018, p. 741.

14.ANDOR, B., DANCIU, C., ALEXA, E., ZUPKO, I., HOGEA, E., CIOCA, A., CORICOVAC, D., PINZARU, I., PATRASCU, J., MIOC, M., CRISTINA, R.T., SOICA, C., DEHELEAN, C., Evidence-Based Complementary and Alternative Medicine, 2016, 2016, Article ID 7638542. http://dx.doi.org/ $10.1155 / 2016 / 7638542$.

15.HOGEA, B.G., ANDOR, B.C., TOTOREAN, A., Rev. Chim. (Bucharest), 69, no 12, 2018, p. 3530.
16.CRETU, O.M., HUT, E.F., DAN, R.G., SIMA, L.V., BLIDISEL, C.I.A., LIGHEZAN, D.F., MUNTEANU, M., RATIU, I.M., Rom. J. Morphol. Embryol., 58, No. 4, 2017, p.1295.

17.SZCZEPIORKOW SKI, Z.M., WINTERS, J.L., BANDARENKO, N., KIM, H.C., LINENBERGER, M.L., MARQUES, M.B., SARODE, R., SCHWARTZ, J., WEINSTEIN, R., SHAZ, B.H., J. Clin. Apher., 25, No. 2, 2010, p. 83. 18.BUDA, V., ANDOR, M., PETRESCU, L., CRISTESCU, C., BAIBATA, D.E., VOICU, M., MUNTEANU, M., CITU, I., MUNTEANU, C., CRETU, O., TOMESCU, M.C., Int. J. Mol. Sci., 18, No. 2, 2017, p. 348. doi: 10.3390/ijms18020348.

19.ROSCA, C., MUNTEANU, M., TAMASOI, I., PETROVIC, Z., BALICA, N., NICULA, C., CRETU, O.M., Acta Ophthalmologica, 94, No.6, 2016, p. 625.

20.NEAMTU, C., TOTOLICI, B.D., CRETU, O.M., STANESCU, C., ARDELEAN, A., BADEA, O., PRIBAC, G.C., CIOBANU, M.O., MATEESCU, G.O., MOGOANTA, S.S., Rom. J. Morphol. Embryol., 58, No.1, 2017, p.235.

21.BUDA, V., ANDOR, M., CRISTESCU, C., VOICU, M., SUCIU, L., MUNTEAN, C., CRETU, O., BAIBATA, D.E., GHEORGHIU, C.M., TOMESCU, M.C., Farmacia, 64, No. 3, 2016, p. 382.

22.FOLESCU, R., ZAMFIR, C.L., SISU, A.M., MOTOC, A.G.M., ILIE, A.C., MOISE, M., Rom. J. Morphol. Embryol., 55, No.3, 2014, p. 797.

23.RUSU, M.C., CERGAN, R., DERMENGIU, D., CURCA, G.C., FOLESCU, R., MOTOC, A.G.M., JIANU, A.M., Clinical Anatomy, 23, No.1, 2010, p. 93.

24.MOISE, M., BURUIAN, M.M., ILIE, C., ZAMFIR, C.L., FOLESCU, R., MOTOC, A.G.M., Rom. J. Morphol. Embryol., 54, No.4, 2013, p. 961. 25.NUSSBAUM, L.A., OGODESCU, A., HOGEA, L., NUSSBAUM, L.M., ZETU, I., Rev Cercet. Interv. Soc., 56, 2017, p. 114.

26.GUYATT, G., GUTTERMAN, D., BAUMANN, M.H., ADDRIZZO-HARRIS, D., HYLEK, E.M., PHILLIPS, B., RASKOB, G., LEWIS, S.Z., SCHUNEMANN, H. Chest, 129, No.1, 2006, p. 174.

27.FAUR, A.C., SAS, I., MOTOC, A.G.M., CORNIANU, M., ZAMFIR, C.L., LAZAR, D.C., FOLESCU, R., Rom. J. Morphol. Embryol., 56, No. 4, 2015, p. 1429.

28.HOGEA, L.M., NUSSBAUM, L.A., CHIRIAC, D.V., AGEU, L.S., ANDREESCU, N.I., GRIGORAS, M.L., FOLESCU, R., BREDICEAN, A.C., PUIU, M., ROSCA, E.C.I., SIMU, M.A., LEVAI, C.M., Rom. J. Morphol. Embryol., 58, No.3, 2017, p. 767.

29.NUSSBAUM, L.A., HOGEA, L.M., CHIRIAC, D.V., GRIGORAS, M.L., FOLESCU, R., BREDICEAN, A.C., ROSCA, E.C.I., MUNCAN, B., NUSSBAUM, L.M., SIMU, M.A., LEVAI, C.M, Rom. J. Morphol. Embryol., 58, No.4, 2017, p. 1435.

30.HOGEA, L.M., SAS, I.T., POROCH, V., NUSSBAUM, L.A., SAS, I., SERBAN, D., ERDELEAN, D., FOLESCU, R., ZAMFIR, C.L., BREDICEAN, A.C., SIMU, M.A., Rev Chim. (Bucharest), 69, no. 4, 2018, p. 934.

31.STEVANOVIC, D., BAGHERI, Z., ATILOLA, O., VOSTANIS, P., STUPAR, D., MOREIRA, P., FRANIC, T., DAVIDOVIC, N., KNEZ, R., NIKSIC, A., DODIG-CURKOVIC, K., AVICENNA, M., THABET, A.A., PETROV, P., UBALDE, D., MONTEIRO, L.A., RIBAS, R., Epidemiology and Psychiatric Sciences, 26, No. 4, 2017, p. 430.

32.ALEXA, A.I., CANTEMIR, A., ANTIOCH, I., ALMUS, I.M., COJOCARU, S., GARDIKIOTIS, R., LUCA, A., FILIP, M.A., ABABEI, D.C., ZAMFIR, C.L., Rev Chim. (Bucharest), 68, no. 2, 2017, p. 350.

33.POPESCU, M.R., ZUGUN, F.E., COJ OCARU, E., TOCAN, L., FOLESCU, R., ZAMFIR, C.L., Rom. J. Morphol. Embryol., 54, No.2, 2013, p. 399.

Manuscript received: 14.09 .2018 